\title{
IgA lambda oligoclonal gammopathy in multiple myeloma
}

\author{
Oligoklonal gammopati ile prezante olan bir Ig A multipl miyelom olgusu
}

\author{
Ibrahim Tek¹, Dilsa Mızrak2, Güngör Utkan¹, Selami Koçak Toprak³, Hüseyin Tutkak,

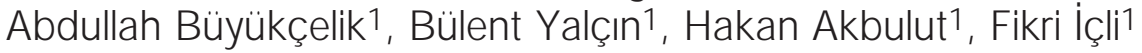 \\ ${ }^{1}$ Department of Medical Oncology, Ankara University School of Medicine, Ankara, Turkey \\ 2Department of Internal Medicine, Ankara University School of Medicine, Ankara, Turkey \\ ${ }^{3}$ Department of Hematology, Ankara University School of Medicine, Ankara, Turkey \\ ${ }^{4}$ Department of Clinical Immunology and Rheumatology, Ankara University School of Medicine, Ankara, Turkey
}

\section{To the Editor,}

Multiple myeloma is a disorder in which malignant plasma cells, generally derived from one clone, accumulate in the bone marrow [1]. Electrophoresis of plasma proteins is used as a diagnostic test for this disorder [2,3]. In rare conditions, electrophoresis produces more than one narrow peak simultaneously, suggesting the existence of more than one clonal antibody and establishing a biclonal, triclonal or oligoclonal gammopathy [3].

A 56-year-old male was referred to our hospital in September 2005 with low-back pain. The physical examination was normal, except for muscle weakness of the bilateral lower extremities. The laboratory examination findings were as follows: hemoglobin $11.8 \mathrm{~g} / \mathrm{dl}$, white cell count $3.8 \times 10^{9} / \mathrm{L}$, erythrocyte sedimentation rate $102 \mathrm{~mm} / \mathrm{h}$ and globulin $2.7 \mathrm{~g} / \mathrm{dl}$. Serum lgG was $3.98 \mathrm{~g} / \mathrm{dl}$ (7-16), IgA $9.7 \mathrm{~g} / \mathrm{dl}(0.7-4), \lg M 0.43$ $\mathrm{g} / \mathrm{dl}$ (0.4-2.3), lambda light chain $3.94 \mathrm{~g} / \mathrm{L}$ (0.9-2.1), and kappa light chain $1.25 \mathrm{~g} / \mathrm{L}$ (1.7-3.78). Serum protein electrophoresis showed four clonal bands on the gamma region. Capillary immunofixation of the serum revealed the presence of $\lg A$ lambda oligoclonal gammopathy (Figure 1). The liver and kidney functions were normal. X-ray films of the bones revealed lytic areas in the skull, pelvis and the ribs. Bone marrow aspiration showed hypercellularity with approximately $30 \%$ infiltration of low differentiated plasma cells. Informed consent was obtained from the patient.

A homogeneous spike-like peak in a focal region of the gamma-globulin zone indicates a monoclonal gammopathy.
Both neoplastic and non-neoplastic disorders are associated with monoclonal paraproteinemia [4]. Biclonal gammopathy is associated with similar disorders [5]. The distribution between various clinical entities, the clinical features of the patients as well as the prognosis seem to be similar to those of monoclonal gammopathies [6]. In contrast, polyclonal gammopathies may be caused by any reactive or inflammatory process [7]. They are characterized by a broad diffuse band with one or more heavy chains and kappa and lambda light chains. Protein electrophoresis is extremely valuable for recognizing cases of

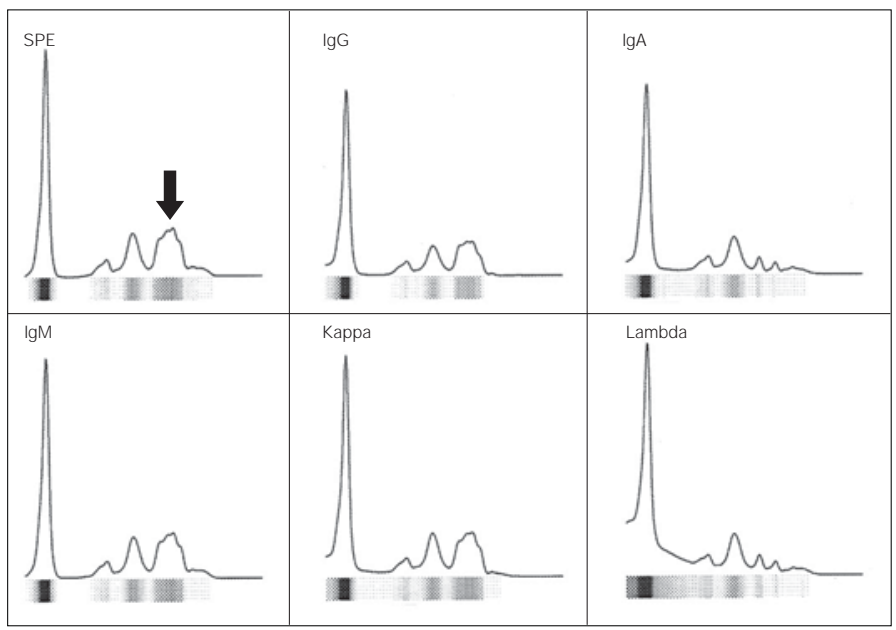

Figure 1. Capillary immunofixation of the serum revealed the presence of $\lg \mathrm{A}$ lambda oligoclonal gammopathy (arrow) 
monoclonal gammopathies and for following quantitative changes in spikes. M-proteins appear as tall, narrow, sharply defined peaks that reflect their structural homogeneity. They are usually located in the $\gamma$ or $\gamma$ - $\beta$ region. IgA spikes are usually broader, as seen in our case, because the molecule tends to form polymers of different sizes (4). The prevalence of mono and biclonal gammopathies in the general population ranges between $1-3 \%$, but only $1 \%$ of these are biclonal [3].

In conclusion, our case is the first report of multiple myeloma that is derived from four clones. Immunoelectrophoresis showed that all four clones included the same heavy and light chain.

\section{Conflict of interest}

No author of this paper has a conflict of interest, including specific financial interests, relationships, and/or affiliations relevant to the subject matter or materials included in this manuscript.

\section{References}

1. Sirohi B, Powles R. Multiple myeloma. Lancet 2004;363:875-87.

2. Longo DL, Anderson KC. Plasma cell disorders. In: Kasper, DL, Fauci AS, Longo DL, et al., editors. Harrison's Principles of Internal Medicine. New York: McGraw-Hill, 2005: 656-62.

3. Cohen $Y$, Ben-Bassat I. Biclonal gammopathies: clinical and theoretical aspects. Harefuah 1993;124:393-5, 456.

4. Berenson JR, Casciato DA. Plasma cell dyscrasias and Waldenström's macroglobulinemia. In: Manual of Clinical Oncology. 5th ed. 2004: 458-79.

5. Alanoglu G, Ozet G, Davla K, Kuzu I, Erekul S, ilhan O, Beksaç M. Extramedullary presentation of biclonal IgGk and IgAk multiple myeloma. Turk J Haematol 2002;19:421-5.

6. Kyle RA, Robinson RA, Katzmann JA. The clinical aspects of biclonal gammopathies. Am J Med 1981;71:999-1008.

7. O'Connell TX, Horita TJ , Kasravi B. Understanding and interpreting serum protein electrophoresis. Am Fam Physician 2005;71:105-12. 